\title{
Seropositivity and Coinfection of Hepatitis B and C among Patients Seeking Hospital Care in Islamabad, Pakistan
}

\author{
Jafar Khan, ${ }^{1}$ Mehwish Shafiq, ${ }^{1}$ Sameera Mushtaq, ${ }^{1}$ Sultan Ayaz, ${ }^{2}$ Riaz Ullah, ${ }^{3}$ \\ Naser M. AbdEI-Salam, ${ }^{4}$ H. Fouad, ${ }^{4}$ and Mohammad Abdul Wasim ${ }^{5}$ \\ ${ }^{1}$ Department of Microbiology, Kohat University of Science and Technology, Kohat 26000, Khyber Pakhtunkhwa, Pakistan \\ ${ }^{2}$ Department of Zoology, Kohat University of Science and Technology, Kohat 26000, Pakistan \\ ${ }^{3}$ Department of Chemistry, Government College Ara Khel, FR Kohat 26000, Pakistan \\ ${ }^{4}$ Riyadh Community College, King Saud University, Riyadh 11437, Saudi Arabia \\ ${ }^{5}$ Department of Chemistry, Sarhad University of Science and Information Technology, Peshawar 25000, Pakistan
}

Correspondence should be addressed to Riaz Ullah; afridiriaz@yahoo.com

Received 22 February 2014; Revised 19 May 2014; Accepted 28 May 2014; Published 24 June 2014

Academic Editor: Giulia Morsica

Copyright (C) 2014 Jafar Khan et al. This is an open access article distributed under the Creative Commons Attribution License, which permits unrestricted use, distribution, and reproduction in any medium, provided the original work is properly cited.

\begin{abstract}
The undertaken study was conducted to find out the seroprevalence and coinfection of HBV and HCV infection among patients seeking hospital care. A total of 845 samples were received at tertiary care hospital of Islamabad and were screened for hepatitis B and C. The ELISA was used to detect antigen for HBV and antibodies for HCV in patient serum. Among 845 collected samples, 255 (30.1\%) were seropositive for HBV and HCV. Out of 255 seropositive samples, 45 (5.3\%) were positive for HBsAg while 199 (23.5\%) were positive for anti-HCV. Among 255, 11 (1.3\%) were seropositive for both HBsAg and anti-HCV (coinfection). Among the seropositive male, HBV was more prevalent (23.8\%) while female patients had a high incidence of HCV (52.2\%). Among the age group variable, HBV, HCV, and coinfection were found to be more common in the age groups of 21-30 (29\%) and 30-40 (24\%) years. The seropositivity for HBsAg was higher in unmarried individuals (31.2\%) while anti-HCV was more prevalent in married individuals (84\%). The present study provides the preliminary information about high HCV and HBV prevalence. Findings from the current study will be helpful for the better management and control of viral hepatitis among patients seeking hospital care.
\end{abstract}

\section{Introduction}

Viral hepatitis is a major health problem in all parts of world. $\mathrm{HBV}$ and $\mathrm{HCV}$ are hepatotropic viruses leading to significant morbidity and mortality worldwide $[1,2]$. HBV is a member of Hepadnaviridae family harboring a DNA genome while $\mathrm{HCV}$ is RNA virus that belongs to Flaviviridae family [3].

Hepatitis B and C are transmitted parentally mainly as a result of blood contact, including injury with contaminated instruments and sharing of needles, or by sexual contact and also through parental transmission from mother to child [4]. Hepatitis B and C infections can lead to an acute or silent course of liver disease progressing from liver impairment to liver failure, cirrhosis of liver, and hepatocellular carcinoma $[1,2]$.

The global prevalence of $\mathrm{HCV}$ is about $2.8 \%$; while more than 185 million people are infected with $\mathrm{HCV}$ alone, $\mathrm{HBV}$ prevalence is variable around the globe; however, among the 2 billion people infected with HBV, about 360 million people are chronic carriers around the world $[2,5]$. South and Southeast Asian countries have estimated prevalence rate from 1.5 to $3.5 \%$ [2]. In Pakistan the seroprevalence of hepatitis B surface antigen (HBsAg) and HCV antibodies is about $2.5 \%$ and $4.8 \%$, respectively, with an overall infection rate of $7.6 \%$ in the general population [6].

$\mathrm{HBV}$ and HCV may appear as coinfection due to the same mode of transmission $[4,7]$. Several studies documented that HBV and HCV coinfection accelerates liver disease progression and increases the risk of hepatocellular carcinoma [79], and the patients need high dose of interferon treatment [10]. Although a growing body of the literature is available on the prevalence of HCV and HBV [6, 11, 12], limited data is documented on the coinfection of HBV and HCV from Islamabad. 
The present study reported the seroprevalence and coinfection of HBV and HCV among patients seeking hospital care in Islamabad. Findings from this study may be helpful to formulate strategy for the prevention of $\mathrm{HBV}$ and $\mathrm{HCV}$ coinfection.

\section{Materials and Methods}

2.1. Study Area. The study was conducted from 1st July to 31st August, 2011, at Pakistan Institute of Medical Sciences (PIMS), Islamabad. All the patient seeking hospital care were enrolled in the study.

2.2. Sample Collection. During this period a total of 845 blood samples from patients seeking hospital care suspected for viral hepatitis were collected in sterilized vacutainer, dully labeled with sex, age, areas, and date of collection, and kept in refrigerator at $-20^{\circ} \mathrm{C}$ for further process.

2.3. Sample Screening. A total of 845 blood samples were screened for detection of $\mathrm{HBV}$ and $\mathrm{HCV}$ using ICT (immunochromatography test). The screen samples were further subjected to ELISA for reconfirmation of the test.

2.4. Enzyme Linked Immunosorbent Assay (ELISA). For detection of HBsAg and HCV antibodies two types of ELISA kits were used. HbsAg ELISA kit is an enzyme-linked immunosorbent assay (ELISA) for qualitative detection of $\mathrm{HBsAg}$ in human serum or plasma. For detection of HBsAg with ELISA kit, sandwich ELISA method was used. HCV ELISA kit is an enzyme-linked immunosorbent assay for qualitative detection of antibodies to hepatitis $\mathrm{C}$ virus in human serum or plasma. For HCV antibody detection indirect ELISA was employed. The Biokit ELISA system (BEST 2000) was used for running ELISA.

2.5. Data Analysis. The data was analyzed with Window 7, Microsoft Excel 2007 (Microsoft, USA).

\section{Results and Discussion}

Of total 845 collected samples, 255 (30.1\%) samples were positive for hepatitis B and C. Out of 255 samples, 45 (5.3\%) were positive for HBsAg while 199 (23.5\%) were positive for anti-HCV. Among 255, 11 (1.3\%) were seropositive for both HBsAg and anti-HCV (coinfection) (Table 1). Among the seropositive male $(n=122,47.8 \%)$, HBV was more prevalent $(n=29,23.8 \%)$ while female patients $(n=112,84.2 \%)$ had a high frequency of $\mathrm{HCV}(n=133,52.2 \%)$. The coinfection rate was higher in male individuals $(n=06,4.9 \%)$ as compared to female patients $(n=05,3.8 \%)$ (Table 2$)$. Among the age group variable $\mathrm{HBV}, \mathrm{HCV}$, and coinfection were found to be more frequent in the age groups of 21-30 $(n=74,29 \%)$ and 30-40 $(n=63,24 \%)$ years while age groups of $1-9$ $(n=04,02 \%)$ and $70-80(n=04,02 \%)$ years are less infected by HBV and HCV (Table 3 ). The seropositivity for HBsAg was higher in unmarried individuals $(n=25,31.2 \%)$ while anti-HCV was more prevalent in married individuals
TABLE 1: Incidence of HBV, HCV, and coinfection. $N=845$.

\begin{tabular}{lc}
\hline Serological markers & $\begin{array}{c}\text { Seroprevalence } \\
n(\%)\end{array}$ \\
\hline HBsAg & $45(5.3)$ \\
Anti-HCV & $199(23.5)$ \\
Coinfection & $11(1.30)$ \\
\hline Overall seropositivity & $255(30.1)$ \\
\hline
\end{tabular}

TABLE 2: Gender-wise seropositivity of hepatitis B, C, and coinfection. $n=845$.

\begin{tabular}{|c|c|c|c|}
\hline \multirow[b]{2}{*}{ Serological markers } & \multicolumn{2}{|c|}{ Gender } & \multirow[b]{2}{*}{$\begin{array}{c}\text { Total prevalence } \\
n(\%)\end{array}$} \\
\hline & $\begin{array}{l}\text { Male } \\
n(\%)\end{array}$ & $\begin{array}{c}\text { Female } \\
n(\%)\end{array}$ & \\
\hline HBsAg & $29(23.8)$ & $16(12)$ & $45(5.32 \%)$ \\
\hline Anti-HCV & $87(71.3)$ & $112(84.2)$ & $199(23.55 \%)$ \\
\hline Coinfection & $06(4.9)$ & $05(3.8)$ & $11(1.3 \%)$ \\
\hline Total & $122(47.8)$ & $133(52.2)$ & $255(30.1 \%)$ \\
\hline
\end{tabular}

TABLE 3: Seropositivity of HBsAg, anti-HCV, and coinfection in different age groups.

\begin{tabular}{lcccc}
\hline Age groups & $\begin{array}{c}\text { HBsAg } \\
\text { positive }\end{array}$ & $\begin{array}{c}\text { Anti-HCV } \\
\text { positive }\end{array}$ & $\begin{array}{c}\text { Coinfection } \\
\text { positive }\end{array}$ & $\begin{array}{c}\text { Total } \\
+(\%)\end{array}$ \\
\hline $1-9$ & 01 & 03 & 00 & $04(0.47 \%)$ \\
$10-20$ & 07 & 11 & 01 & $19(2.24 \%)$ \\
$21-30$ & 18 & 53 & 03 & $74(8.75 \%)^{\star}$ \\
$30-40$ & 09 & 52 & 02 & $63(7.45 \%)^{\star}$ \\
$41-50$ & 08 & 40 & 03 & $51(6.03 \%)^{\star}$ \\
$51-60$ & 03 & 20 & 01 & $24(2.84 \%)$ \\
$61-70$ & 00 & 15 & 01 & $16(1.8 \%)$ \\
$71-80$ & 00 & 03 & 01 & $04(0.47 \%)$ \\
\hline Total & 46 & 197 & 12 & $255(30.1 \%)^{\star}$ \\
\hline "Statistical analysis; univariate ANOVA. Significant $(P<0.05)$.
\end{tabular}

$(n=147,84 \%)$ (Table 4). Moreover, samples collected from General $(n=87,34.1 \%)$ and Gastroenterology 54 (21.1) ward showed increased HCV and HBV infection rates. The samples collected from Pulmonology ward showed less seropositivity for HBV and $\mathrm{HCV}(n=03,1.1 \%)$ markers (Table 5). Viral hepatitis is a major health problem worldwide. HBV and HCV are becoming endemic for the entire world. HBV and HCV cause coinfection due to the same transmission mode $[4,7]$. Investigating the coinfection HBV and HCV is crucial as it may accelerate the course of the liver damage, increase the risk of hepatocellular carcinoma, and affect therapeutic response to antiviral molecules [7-10].

In the present study, a total of 845 hospitalized and nonhospitalized suspected viral hepatitis patients were screened for the serodetection of HBV and HCV infection. It was observed that anti-HCV positivity was much higher (23.5\%) compared to HBsAg (5.3\%). Another study from Rawalpindi reported $\mathrm{HBsAg}$ prevalence $(2.7 \%)$ and $\mathrm{HCV}$ positivity $(10.4 \%)$. These contradictions may exist due to the study on general population and also immunochromatographic 
TABLE 4: Seropositivity of viral hepatitis in different marital status patients. $n=845$.

\begin{tabular}{lccc}
\hline Serological markers & Married & Unmarried & $\begin{array}{c}\text { Total } \\
n(\%)\end{array}$ \\
\hline HBsAg & $21(12)$ & $25(31.2)$ & $46(5.68 \%)^{\star}$ \\
Anti-HCV & $147(84)$ & $50(62.5)$ & $197(23.3 \%)^{\star}$ \\
Coinfection & $07(4)$ & $05(6.2)$ & $12(1.42 \%)$ \\
\hline Total & $175(68.6)$ & $80(31.3)$ & $255(30.1 \%)^{\star}$ \\
\hline
\end{tabular}

`Statistical analysis; univariate ANOVA. Significant $(P<0.05)$.

TABle 5: Seropositivity of hepatitis B, C, and coinfection in patients from different hospital wards and departments $n=845$.

\begin{tabular}{lcccc}
\hline Departments & \multicolumn{2}{c}{ HBsAg } & Anti-HCV Coinfection & Total \\
& positive & positive & positive & $+(\%)$ \\
\hline General ward & 15 & 70 & 02 & $87(10.2 \%)^{\wedge}$ \\
Gastroenterology & 10 & 41 & 03 & $54(6.39 \%)^{\star}$ \\
General medicine & 07 & 33 & 00 & $40(4.73 \%)^{\star}$ \\
Emergency & 08 & 12 & 00 & $20(2.36 \%)^{\star}$ \\
Cardiology & 02 & 08 & 00 & $10(1.18 \%)$ \\
Nephrology & 00 & 08 & $02(18)$ & $10(1.18 \%)$ \\
Dental OPD & 00 & 05 & $01(9)$ & $06(0.71 \%)$ \\
Urology & 00 & 05 & 00 & $05(0.59 \%)$ \\
Ophthalmology & 00 & 04 & $01(9)$ & $05(0.59 \%)$ \\
Pulmonology & 01 & 02 & 00 & $03(0.35 \%)$ \\
Surgical ward & 02 & 07 & $01(9)$ & $10(1.18 \%)$ \\
Psychiatry & 00 & 05 & 00 & $05(0.59 \%)$ \\
\hline Total & 45 & 199 & 11 & $255(30.1 \%)^{\wedge}$ \\
\hline
\end{tabular}

^Statistical analysis; univariate ANOVA, Duncan test. Significant $(P<0.05)$.

techniques (ICT) used for anti-HCV detection by Gul et al. [13]; while in the present study we target hospitalized and nonhospitalized patients, ELISA was used for the detection $\mathrm{HCV}$ antibodies.

The observed coinfection rate of $\mathrm{HBV}$ and $\mathrm{HCV}$ was $1.30 \%$, which is in line with a previous study conducted by Raja et al. which reported the overall coinfection rate of about $1.1 \%$ in viral hepatitis suspected patients referred by different hospitals and clinics [12]. The rate of HBV was more in male patients as compared with female patients which is already reported by Qureshi et al. [6]. This might be the different immune response evoked in both male and female patients. In this study age groups of $21-30$ and $40-50$ years showed highest frequency of HBV and HCV related hepatitis. Other studies also documented high prevalence in age group of 2230 and age group above 40 [13-15]. The possible explanation might be the increased chances of infection in the mentioned age groups. It was observed that HBV was more prevalent in unmarried patients, as HBV can be transmitted through sexual contact [16], and thus these patients are free to indulge in more sexual activity. In case of HCV, married patients were more prone to infection which is in line with a previous study [17]. Furthermore, samples collected form General and
Gastroenterology ward showed increased HCV and HBV infection rate.

\section{Conclusions}

It was concluded from the study that prevalence of HCV and HBV in Pakistan is at an increasing rate. Large-scale studies are needed to understand the epidemiology of HCV and HBV infections. The data of the current study will help in the effective prevention and control measures against $\mathrm{HBV}$ and $\mathrm{HCV}$ infection.

\section{Ethical Approval}

The current research was approved by the Research Ethics Committee of Khyber Medical University, Institute of Medical Sciences Kohat (KIMS). Blood samples were collected after patient consent.

\section{Conflict of Interests}

The authors declare that there is no conflict of interests regarding the publication of this paper.

\section{Acknowledgment}

The authors are thankful to the Deanship of Scientific Research, King Saud University, Riyadh, for funding the work through the research group Project no. RGP-210.

\section{References}

[1] W. Elizabeth, "Global epidemiology of hepatitis B virus, (HBV) infection," North American Journal of Medical Sciences, vol. 4, pp. 7-13, 2011.

[2] M. H. Khayriyyah, J. Groeger, A. D. Flaxman, and S. T. Wiersma, "Global epidemiology of hepatitis C virus infection: new estimates of age-specific antibody to HCV seroprevalence," Hepatology, vol. 57, no. 4, pp. 1333-1342, 2013.

[3] C. Stephane and P. Jean-Michael, "Diagnosis and management of chronic viral hepatitis: antigens, antibodies and viral genomes," Best Practice and Research: Clinical Gastroenterology, vol. 22, no. 6, pp. 1031-1048, 2008.

[4] I. T. Williams, J. F. Perz, and B. P. Bell, "Viral hepatitis transmission in ambulatory health care settings," Clinical Infectious Diseases, vol. 38, no. 11, pp. 1592-1598, 2004.

[5] World Health Organization, "Hepatitis B vaccines," Weekly Epidemiological Record, vol. 40, pp. 405-420, 2009.

[6] H. Qureshi, K. M. Bile, R. Jooma, S. E. Alam, and H. U. R. Afridi, "Prevalence of hepatitis B and C viral infections in pakistan: findings of a national survey appealing for effective prevention and control measures," Eastern Mediterranean Health Journal, vol. 16, pp. 15-23, 2010.

[7] S. Jamma, G. Hussain, and D. T.-Y. Lau, "Current concepts of HBV/HCV coinfection: coexistence, but not necessarily in harmony," Current Hepatitis Reports, vol. 9, no. 4, pp. 260-269, 2010.

[8] T.-L. Fong, A. M. di Bisceglie, J. G. Waggoner, S. M. Banks, and J. H. Hoofnagle, "The significance of antibody to hepatitis $\mathrm{C}$ virus 
in patients with chronic hepatitis B," Hepatology, vol. 14, no. 1, pp. 64-67, 1991.

[9] A. S. Mohamed, M. A. Alkarawi, and G. A. Mesa, "Dual infection with hepatitis $C$ and B viruses: clinical and histological study in Saudi patients," Hepato-Gastroenterology, vol. 44, no. 17, pp. 1404-1406, 1997.

[10] E. Villa, A. Grottola, P. Buttafoco et al., "High doses of $\alpha$ interferon are required in chronic hepatitis due to coinfection with hepatitis $B$ virus and hepatitis $C$ virus: long term results of a prospective randomized trial," American Journal of Gastroenterology, vol. 96, no. 10, pp. 2973-2977, 2001.

[11] S. Muhammad, N. Muhammad, and N. Uzma, "Sero-prevalence of HCV and associated infections with HIV and HBV among prisoners in Lahore," Biomedica, vol. 27, pp. 119-122, 2011.

[12] A. Raja, K. Waheed, A. Waqaruddin, E. A. Syed, and A. Ambreen, "Screening of HBsAg and anti HCV from tertiary care, private and public sector hospitals," Pakistan Journal of Medical Research, vol. 50, pp. 20-23, 2011.

[13] A. Gull, N. Jamal, and H. Abbas, "Seropositivity of HbsAg and Anti HCV in Rawalpindi and Islamabad and analysis of risk factors," Annals of Pakistan Institute of Medical Sciences, vol. 5, pp. 242-244, 2009.

[14] G. R. Pennap, A. Yakubu, O. Oyige, and J. Forbi, "Prevalence of hepatitis B and C virus infection among people of a local community in Keffi, Nigeria," African Journal of Microbiology Research, vol. 4, no. 4, pp. 274-278, 2010.

[15] A. Al-Ajlan, "Prevalence of hepatitis B and C among students of health colleges in Saudi Arabia," Eastern Mediterranean Health Journal, vol. 17, no. 10, pp. 759-762, 2011.

[16] R. K. Obi, S. S. Umeh, O. H. Okurede, and L. L. Iroagba, "Prevalence of hepatitis $B$ virus infection among pregnant women in antenatal clinic in PortHarcourt, Nigeria," African Journal of Clinical and Experimental Microbiology, vol. 7, pp. 78-82, 2006.

[17] R. H. Raja, K. Ghazala, Q. Mazhar, A. Muhammad, and K. Azra, "Association of diabetes with hepatitis C. virus, (HCV) infected male and female patients along with different risk factors," International Journal of Agriculture and Biology, vol. 5, pp. 736740, 2007. 

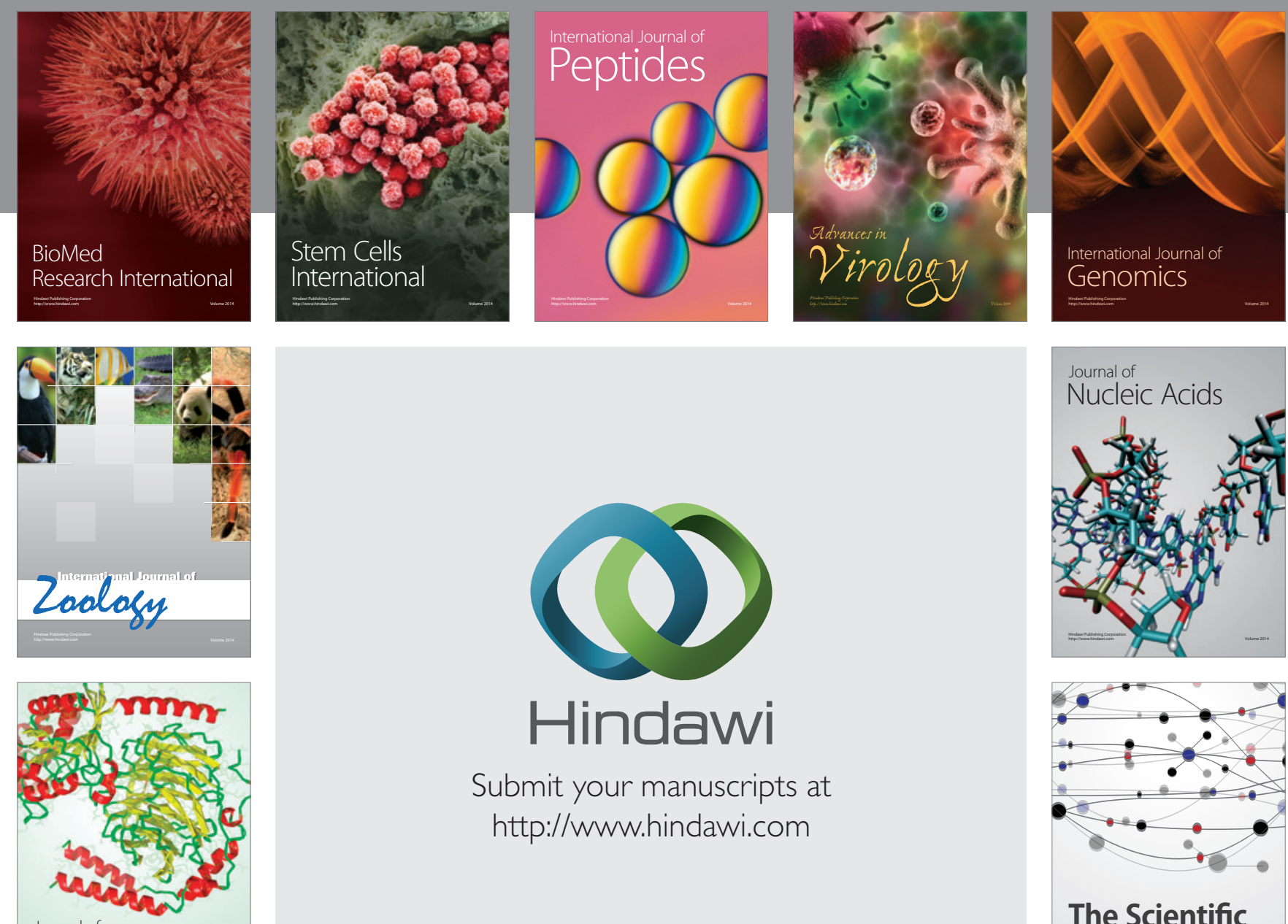

Submit your manuscripts at

http://www.hindawi.com

Journal of
Signal Transduction
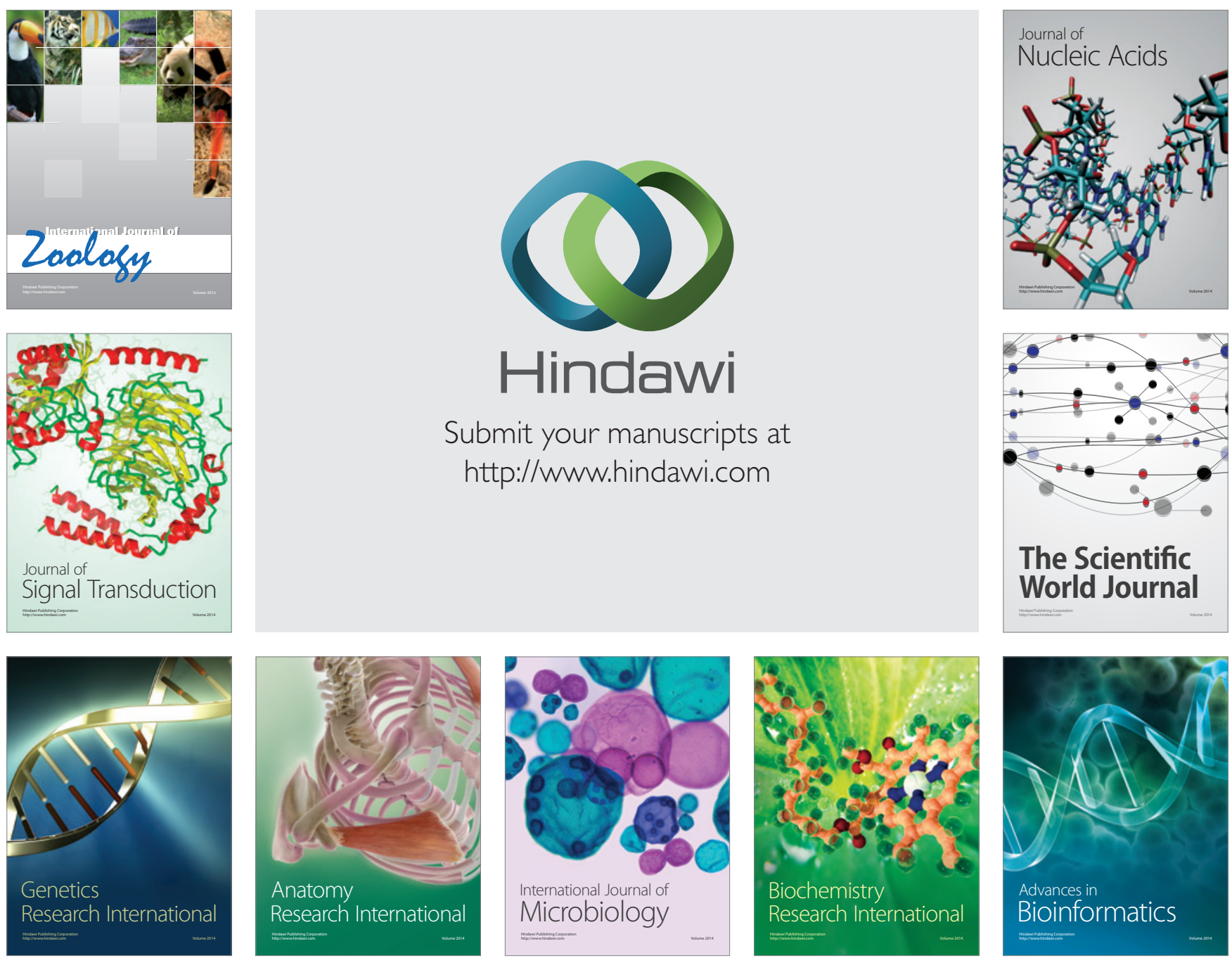

The Scientific World Journal
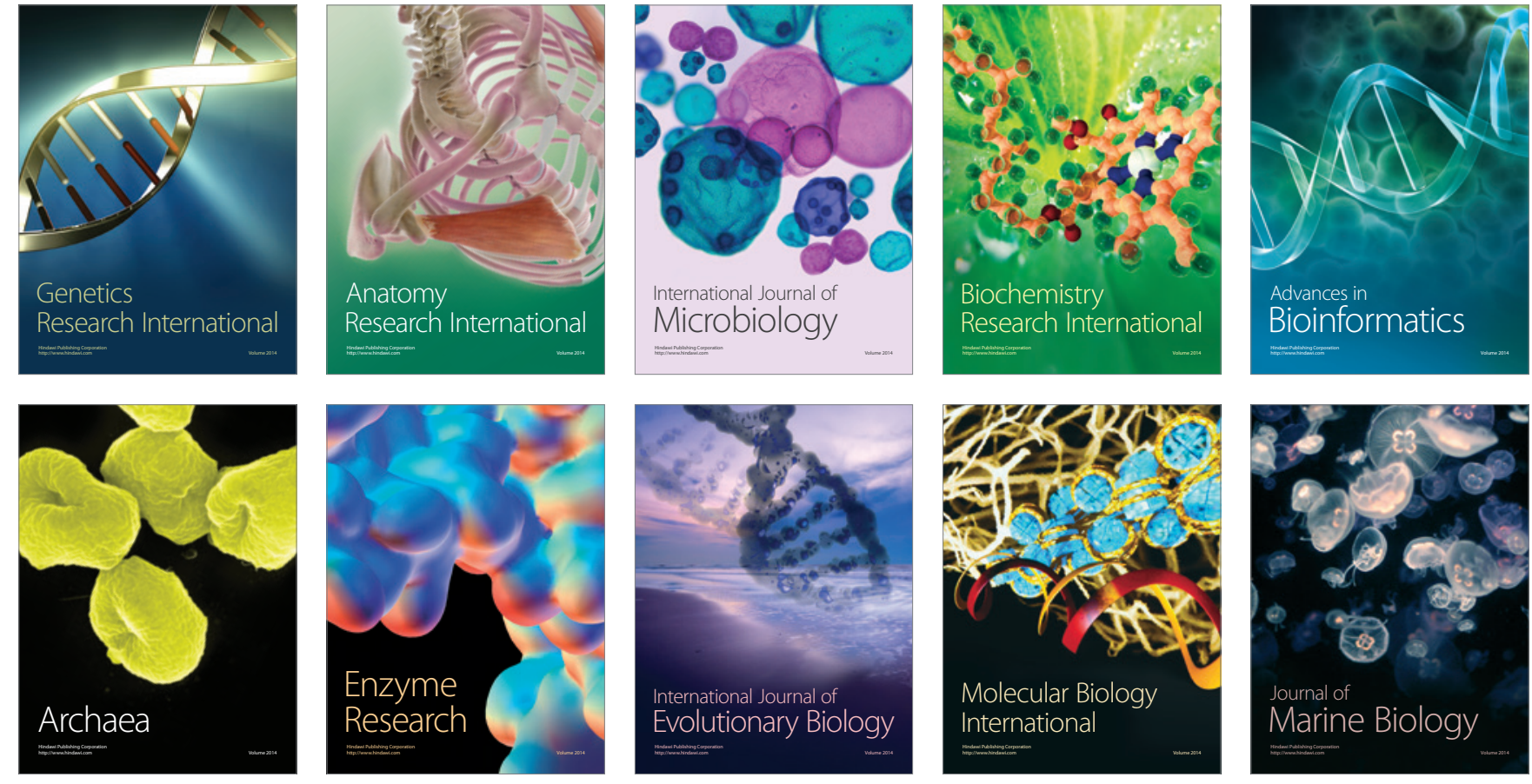